
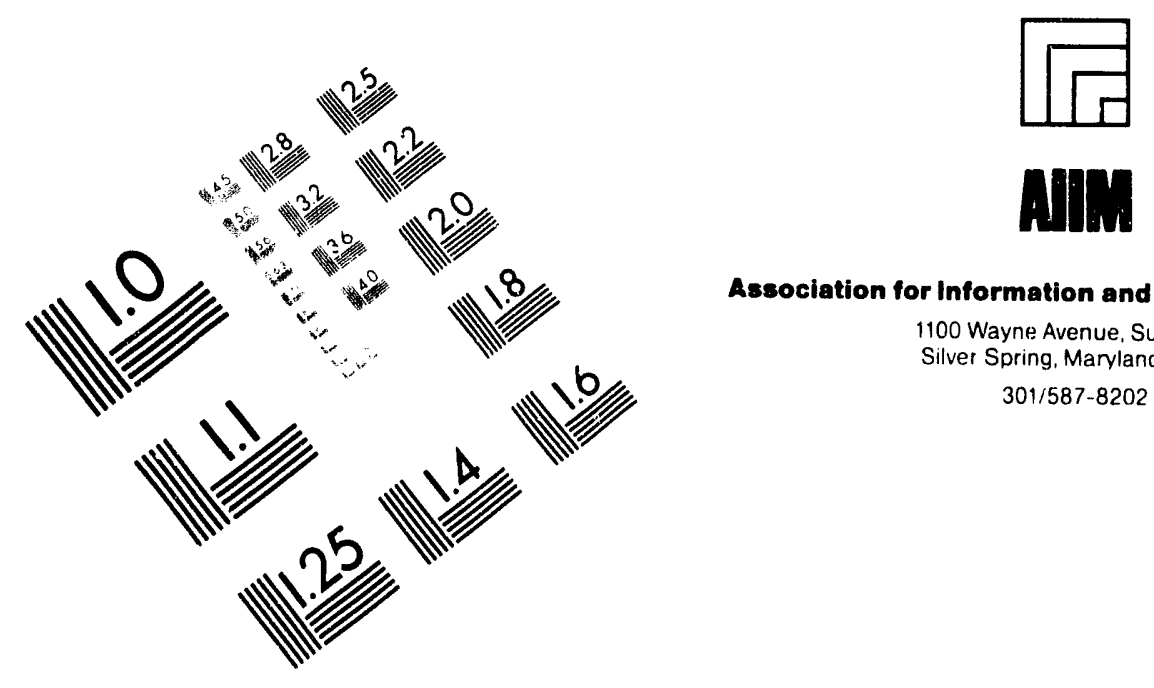

Association for Information and Image Management

1100 Wayne Avenue, Suite 1100

Silver Spring, Maryland 20910

301/587-8202

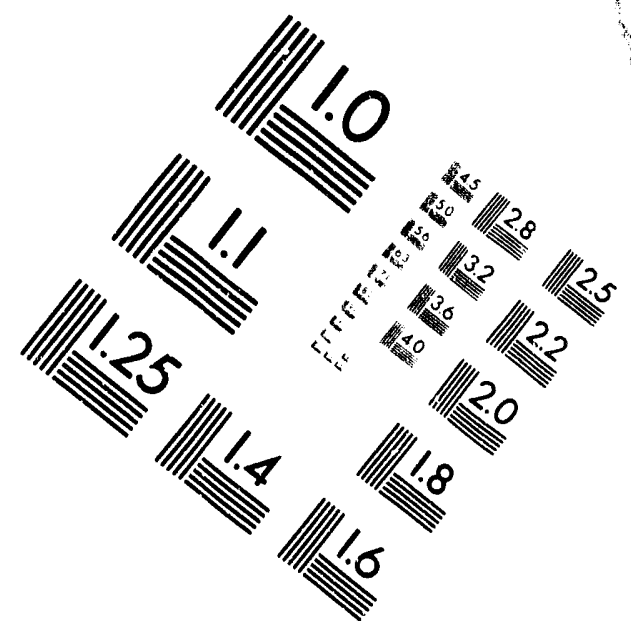

Centimeter

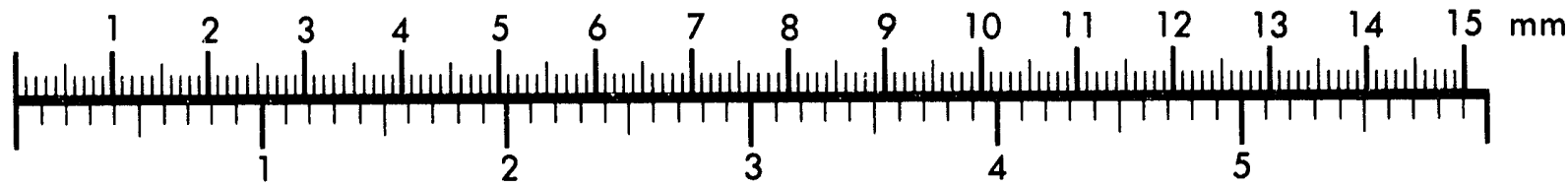

Inches
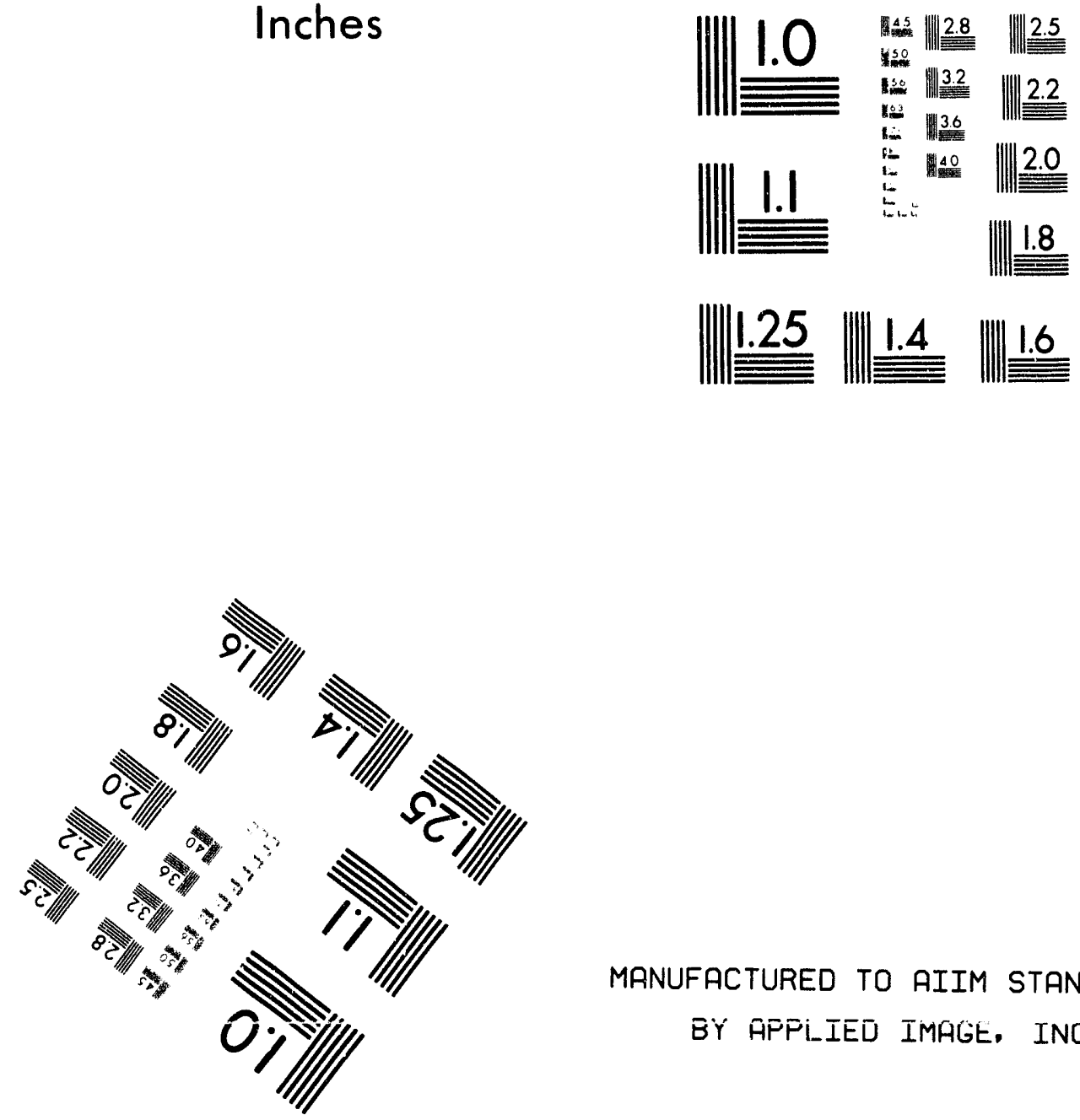

MANUFACTURED TO AIIM STANDARDS

BYY APFiLIED IMAGE, INC.

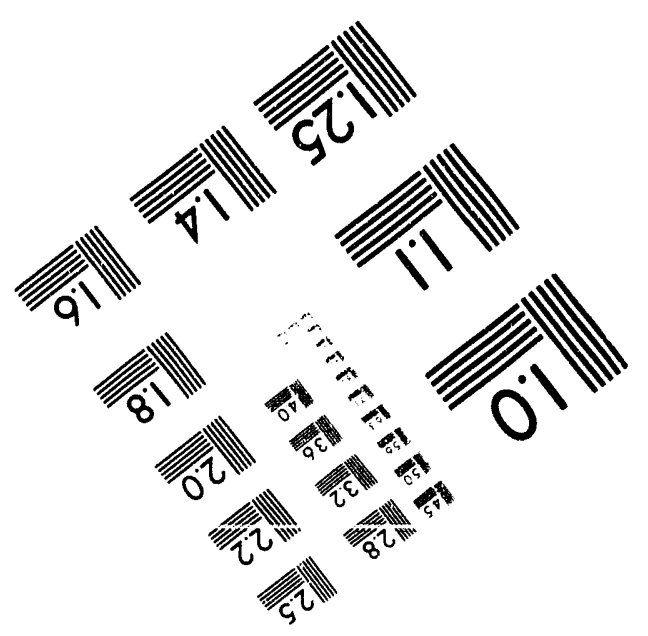



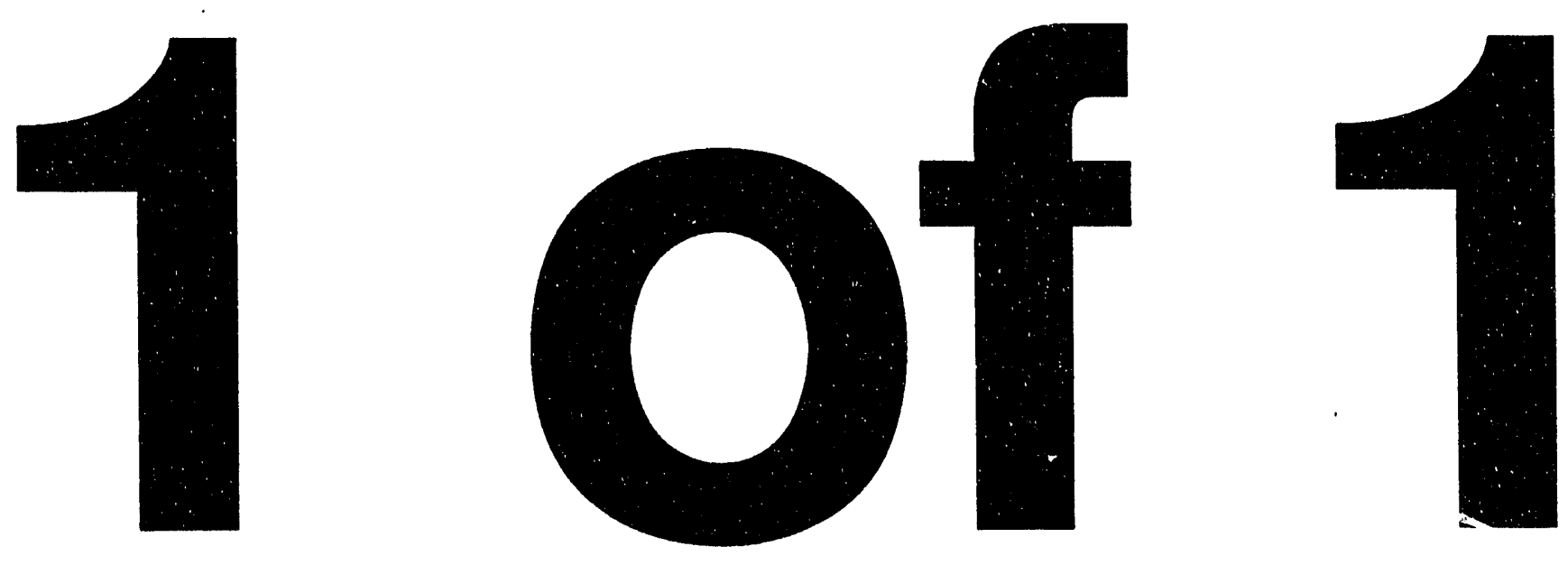


\section{HIGH OCTANE ETHERS FROM SYNTHESIS GAS-DERIVED ALCOHOLS}

Quarterly Technical Progress Report for the Period October-December 1992

Kamil Klier and Richard G. Herman with

Marie A. Johansson and Owen C. Feeley

Zettlemoyer Center for Surface Studies and Department of Chemistry

LEHIGH UNIVERSITY

Bethlehem, PA 18015

February 1993

(Revised April 1993)

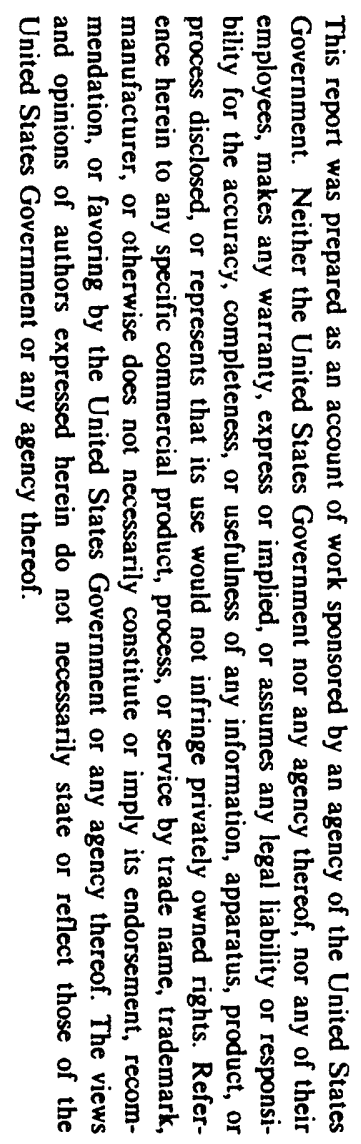

PREPARED FOR THE

U. S. DEPARTMENT OF ENERGY

PITTSBURGH ENERGY TECHNOLOGY CENTER

Contract Ne. DE-AC22-90PC90044 


\section{HIGH OCTANE ETHERS FROM SYNTHESIS GAS-DERIVED ALCOHOLS}

\section{Disclaimer}

This report was prepared as an account of work sponsored by the United States Government. Neither the United States nor the United States DOE, nor any of their employees, nor any of their contractors, subcontractors, or their employees, makes any warranty, express or implied, or assumes any legal liability or responsibility for the accuracy, completeness, or usefulness of any information, apparatus, product or process disclosed, or represents that its use would not infringe privately owned rights. 


\section{HIGH OCTANE ETHERS FROM SYNTHESIS GAS-DERIVED ALCOHOLS}

\section{OBJECTIVES OF THE RESEARCH}

The objective of the proposed research is to synthesize high octane ethers, primarily methyl isobutyl ether (MIBE) and methyl tertiary butyl ether (MTBE), directly from $\mathrm{H}_{2} / \mathrm{CO} / \mathrm{CO}_{2}$ coal-derived synthesis gas via alcohol mixtures that are rich in methanol and 2-methyl-1-propanol (isobutanol). The overall scheme involves gasification of coal, purification and shifting of the synthesis gas, higher alcohol synthesis, and direct synthesis of ethers.

The last stage of the synthesis involves direct coupling of synthesis gas-derived methanol and isobutanol that has been demonstrated by us to occur over superacid catalysts to yield methyl isobutyl ether (MIBE) at moderate pressures and a mixture of methanol and isobutene at low pressures. MIBE is an isomer of MTBE and a process is proposed whereby MTBE from the two alcohols is maximized and MIBE is minimized. This will be achieved by the proper choice of reaction conditions, i.e. intermediate pressures, and of inorganic acid catalysts that are stable at temperatures higher than $200^{\circ} \mathrm{C}$, at which the carbonium ion reaction coupling of the two alcohols to MTBE is more effective than the oxonium ion or ester reaction coupling to MIBE.

Both organic and inorganic catalysts will be investigated, and the better catalysts of these classes will be subjected to long term performance studies. The long term performance studies of the combined process will extend to $1000 \mathrm{hr}$ and detailed analytical data for all products will be provided. The project is divided into the following three tasks: 
Task 1. Synthesis of High Octane Ethers from Alcohol Mixtures Containing Predominantly Methanol and 2-Methyl-1-Propanol over Superacid Resins

Task 2. Inorganic Catalysts for the Synthesis of High Octane Ethers from Alcohols

Task 3. Long Term Performance and Reaction Engineering for Scale-Up of the Alcohols-to-Ethers Process

The expected result of the proposed research is a novel process for producing ethers, in particular MTBE, in which all five carbons of the unsymmetric $\mathrm{C}_{1}-\mathrm{O}-\mathrm{C}_{4}$ ethers originate from coal-derived synthesis gas. 


\section{HIGH OCTANE ETHERS FROM SYNTHESIS GAS-DERIVED ALCOHOLS SUMMARY OF TECHNICAL PROGRESS}

The testing of strongly acidic catalysts for the conversion of a mixture of methanol and isobutanol to ethers and hydrocarbons was continued. Under standardized test conditions the catalysts tested this quarter were: phosphotungstic acid supported on zirconia $\left(\mathrm{PW}_{12} / \mathrm{ZrO}_{2}\right)$, "niobic acid" $\left(\mathrm{Nb}_{2} \mathrm{O}_{5} \cdot \mathrm{xH}_{2} \mathrm{O}\right)$, and an iron and manganese doped sulfatemodified zirconia $\left(\mathrm{Fe} / \mathrm{Mn} / \mathrm{ZrO}_{2} / \mathrm{SO}_{4}{ }^{2-}\right)$. The overall activity of these catalysts followed the order of $\mathrm{Fe} / \mathrm{Mn} / \mathrm{ZrO}_{2} / \mathrm{SO}_{4}{ }^{2-}>\mathrm{PW}_{12} / \mathrm{ZrO}_{2}>\mathrm{Nb}_{2} \mathrm{O}_{5} \cdot \mathrm{xH}_{2} \mathrm{O}$ with the $\mathrm{Fe} / \mathrm{Mn} / \mathrm{ZrO}_{2} / \mathrm{SO}_{4}{ }^{2-}$ catalyst approaching $\mathrm{ZrO}_{2} / \mathrm{SO}_{4}{ }^{2-}$ in both activity and selectivity for isobutene production.

The effect of the presence of water on the reaction of methanol and isobutanol over $\mathrm{ZrO}_{2} / \mathrm{SO}_{4}{ }^{2-}$ was determined to be insignificant under the reaction conditions investigated. At $157^{\circ} \mathrm{C}$ and a feed of $2 / 1$ molar ratio methanol/isobutanol under differential reaction conditions, the production of isobutene was unaffected by the addition of 0.05 and 0.10 parts of water to the $2 / 1$ alcohol feed. A water effect might be observable if higher water addition rates were utilized.

Surface areas have been determined for $\mathrm{Fe} / \mathrm{Mn} / \mathrm{ZrO}_{2} / \mathrm{SO}_{4}^{2-}$, niobic acid, and phosphotungstic acid on silica. After calcination, the surface area for $\mathrm{Fe} / \mathrm{Mn} / \mathrm{ZrO}_{2} / \mathrm{SO}_{4}{ }^{2-}$ was found to be $83 \mathrm{~m}^{2} / \mathrm{g}$. Niobic acid and phosphotungstic acid on silica $\left(\mathrm{PW}_{12} / \mathrm{SiO}_{2}\right)$ were found to have surface areas of 118 and $218 \mathrm{~m}^{2} / \mathrm{g}$, respectively. ${ }^{1} \mathrm{H}$ NMR was used to determine if and how much 1-butene was present as a product when isobutanol was dehydrated over sulfate-modified zirconia. It was found to be present in small amounts, $\leq 3 \%$ of the product stream. 


\section{TECHNICAL PROGRESS}

\section{A. Results of Standard Tests Using Supported Heteropolyacid $\mathrm{PW}_{12} / \mathrm{ZrO}_{2}, \mathrm{Nb}_{2} \mathrm{O}_{50}$ and $\mathrm{Fe} / \mathrm{Mn} / \mathrm{ZrO}_{2} / \mathrm{SO}_{4}{ }^{2-}$ Catalysts}

The screening of very strong solid acids as catalysts for the conversion of $\mathrm{MeOH} / \mathrm{i}$ $\mathrm{BuOH}$ mixtures was continued. New catalysts tested were (i) $20 \mathrm{wt} \%$ phosphotungstic acid supported on $\mathrm{ZrO}_{2}\left(\mathrm{PW}_{12} / \mathrm{ZrO}_{2}\right)$, (ii) niobic acid $\left(\mathrm{Nb}_{2} \mathrm{O}_{5} \times \mathrm{xH}_{2} \mathrm{O}\right)$, and (iii) an iron and manganese doped sulfate-modified zirconia $\left(\mathrm{Fe} / \mathrm{Mn} / \mathrm{ZrO}_{2} / \mathrm{SO}_{4}{ }^{2-}\right)$. The preparation and pretreatment of these new catalysts follows.

\section{Preparation}

Supported heteropolyacids are used as heterogeneous catalysts in several industrial applications. They are reported to possess strong acidic character, as well as unique selectivity characteristics in hydration/dehydration reactions. The use of zirconia-supported phosphotungstic acid, designated herein as $\mathrm{PW}_{12} / \mathrm{ZrO}_{2}$, for the standard reaction of a $1 / 1$ molar $\mathrm{MeOH} / \mathrm{i}-\mathrm{EuOH}$ mixture was investigated.

Phosphotungstic acid with a formula of $\mathrm{H}_{3} \mathrm{PW}_{12} \mathrm{O}_{40}$, thus designated as $\mathrm{PW}_{12}$, was obtained from Fisher Scientific, Co. This compound is also sometimes referred to by others as tungstophosphoric acid or 12-polytungstophosphoric acid. An aqueous solution consisting of $1.68 \mathrm{~g}$ of phosphotungstic acid in $5.5 \mathrm{ml}$ of distilled water was prepared. $\operatorname{The} \mathrm{Zr}(\mathrm{OH})_{4}$, $6.72 \mathrm{~g}$, prepared from hydrolysized $\mathrm{ZrOCl}_{2} \cdot 8 \mathrm{H}_{2} \mathrm{O}$, was impregnated with this solution, with constant mixing, to make a $20 \%$ loading of phosphotungstic acid by weight. The impregnated zirconium hydroxide, $\mathrm{PW}_{12} / \mathrm{Zr}(\mathrm{OH})_{4}$, was placed in a $100^{\circ} \mathrm{C}$ oven overnight. The dried sample was then calcined to $300^{\circ} \mathrm{C}$ for $3 \mathrm{hr}$. This calcination temperature was chosen because it is below the decomposition range reported for heteropolyacids. 
"Niobic acid", actually hydrated niobium oxide $\left(\mathrm{Nb}_{2} \mathrm{O}_{5} \times \mathrm{H}_{2} \mathrm{O}\right)$, was calcined at $200^{\circ} \mathrm{C}$ for $2 \mathrm{hr}$. A literature report indicates that high surface area and strong acidity are maintained only with low calcination temperatures such as this (1).

Recently, an iron and manganese doped sulfate-modified zirconia catalyst $\left(\mathrm{Fe} / \mathrm{Mn} / \mathrm{ZrO}_{2} / \mathrm{SO}_{4}{ }^{2-}\right)$ has been reported to possess stronger and more populous acid sites than $\mathrm{ZrO}_{2} / \mathrm{SO}_{4}{ }^{2-}$ (2). This catalyst was also reported to be many times more active for the low temperature isomerization of butane.

The $\mathrm{Fe} / \mathrm{Mn} / \mathrm{ZrO}_{2} / \mathrm{SO}_{4}{ }^{2-}$ catalyst was prepared according to the method described in Ref. 2. This involved first dissolving $73 \mathrm{~g}$ of $\mathrm{ZrOCl}_{2} \cdot 8 \mathrm{H}_{2} \mathrm{O}$ in $c a .100 \mathrm{ml}$ of distilled water. About $700 \mathrm{ml}$ of aqueous ammonia was added, and the solution was stirred for $2 \mathrm{hr}$. The $\mathrm{Zr}(\mathrm{OH})_{4}$ formed was filtered and washed with distilled water until free of chloride ion. This solid was put in an oven at $100^{\circ} \mathrm{C}$ overnight to dry. The solution used to impregnate the $\mathrm{Zr}(\mathrm{OH})_{4}$ consisted of $1.133 \mathrm{~g}\left(\mathrm{NH}_{4}\right)_{2} \mathrm{SO}_{4}, 2.234 \mathrm{~g}$ of $\mathrm{Fe}\left(\mathrm{NO}_{3}\right)_{3} \cdot 9 \mathrm{H}_{2} \mathrm{O}$, and $0.658 \mathrm{~g}$ of a $51 \mathrm{wt} \%$ solution of $\mathrm{Mn}\left(\mathrm{NO}_{3}\right)_{2}$. These salts were dissolved in distilled water to make 26.5 $\mathrm{ml}$ that was used to impregnate $25 \mathrm{~g}$ of $\mathrm{Zr}(\mathrm{OH})_{4}$. The impregnated catalyst was dried in a $110^{\circ} \mathrm{C}$ oven overnight followed by calcination at $620^{\circ} \mathrm{C}$ for $3 \mathrm{hr}$. The catalyst preparation was designed to give $1.5 \% \mathrm{Fe}, 0.5 \% \mathrm{Mn}$, and $4.0 \% \mathrm{SO}_{4}{ }^{2-}$ by weight supported on $\mathrm{ZrO}_{2}$.

\section{Catalytic Testing Results}

The samples were diluted with Pyrex beads, charged to the reactor, and tested using the following reaction conditions:

$\begin{array}{ll}\text { Temperature } & 90,125,150,175^{\circ} \mathrm{C},\left(\text { also } 200 \text { and } 225^{\circ} \mathrm{C} \text { ) }\right. \\ \text { Pressure } & 1 \mathrm{~atm} \\ \text { Methanol feed } & 1.72 \mathrm{~mol} / \mathrm{kg} \text { catalyst } / \mathrm{hr} \\ \text { Isobutanol feed } & 1.72 \mathrm{~mol} / \mathrm{kg} \text { catalyst } / \mathrm{hr} \\ \mathrm{He}+\mathrm{N}_{2} \text { flow } & 16.0 \mathrm{~mol} / \mathrm{kg} \text { catalyst } / \mathrm{hr} \\ \text { Catalyst weight } & 5.0 \mathrm{~g}\end{array}$


The catalytic results for these three samples are presented in two forms. One presentation of the data is in the form of rate of formation of each of the products, with the units of mol of product $/ \mathrm{kg}$ catal $/ \mathrm{hr}$. This is also referred to as the space time yield or the productivity. In this case, the $\%$ conversion and $\%$ selectivity of each reactant can be directly calculated if the space time yields of all significant products are plotted, as they are in this report.

The second representation of the experimental data is \%yield of each of the products. This latter quantity is defined as $(\%$ conversion of one of the reactant $\mathrm{x} \%$ product selectivity)/100. Thus, for $50 \%$ conversion of isobutanol to isobutene with $75 \%$ selectivity, the \%yield would be $37.5 \%$. It can also be directly calculated from the rate of formation, i.e. \%yield $=($ rate of formation of product $/$ rate of reactant flow $) \times 100$. For example, 0.645 mol isobutene $/ \mathrm{kg}$ catal $/ \mathrm{hr}$ under the present reaction conditions $=37.5 \%$ yield. This last definition of \%yield, as written, presumes that one mole of reactant forms one mole of product, e.g. isobutanol to isobutene (or MIBE). However, two moles of methanol can form one mole of dimethylether. In this case, it must be clear whether the \%yield refers to comparisons of products containing the methyl group from methanol or molar conversions of methanol to products. As an example, the formation of $0.129 \mathrm{~mol} \mathrm{DME} / \mathrm{kg}$ catal $/ \mathrm{hr}$ ( $20 \%$ conversion of methanol with $75 \%$ selectivity to DME) would correspond to a \%yield of $15 \%$ because $0.258 \mathrm{~mol}$ of methanol $/ \mathrm{kg}$ catal $/ \mathrm{hr}$ would be converted to DME. If the basis were moles of products formed that contain one or more methyl groups derived from methanol, then the \%yield of DME would be $7.5 \%((0.129 / 1.72) \times 100)$.

The zirconia-supported heteropolyacid catalyst, $\mathrm{PW}_{12} / \mathrm{ZrO}_{2}$, exhibited low activity and poor selectivity, as indicated in Figures 1-3, relative to other catalysts tested previously (3-4). This is especially true with respect to the $\mathrm{SO}_{4}{ }^{2-} / \mathrm{ZrO}_{2}$-based catalyst to be discussed in additional detail later in this report. As shown in Figure 1, isobutene is the principal 


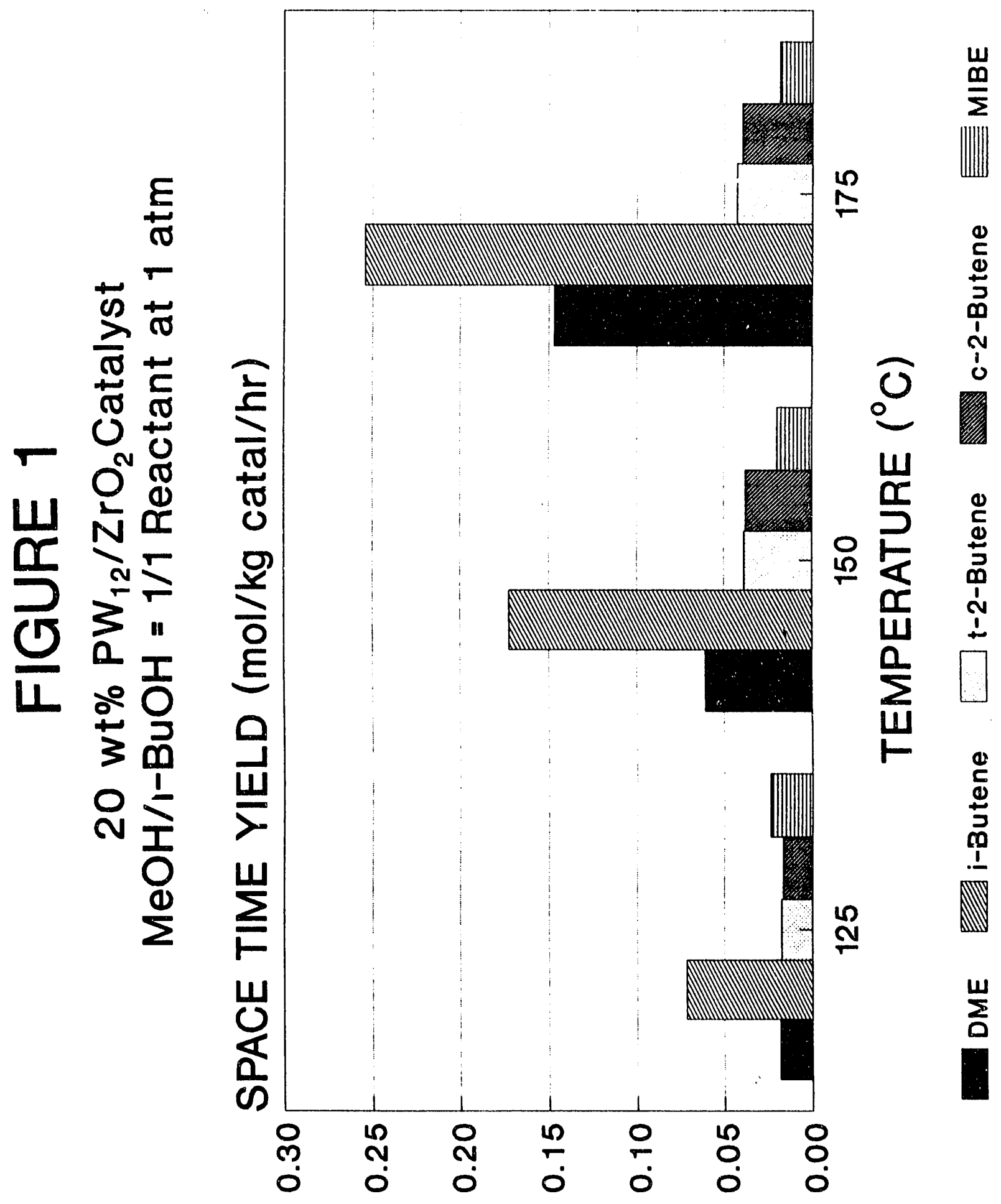




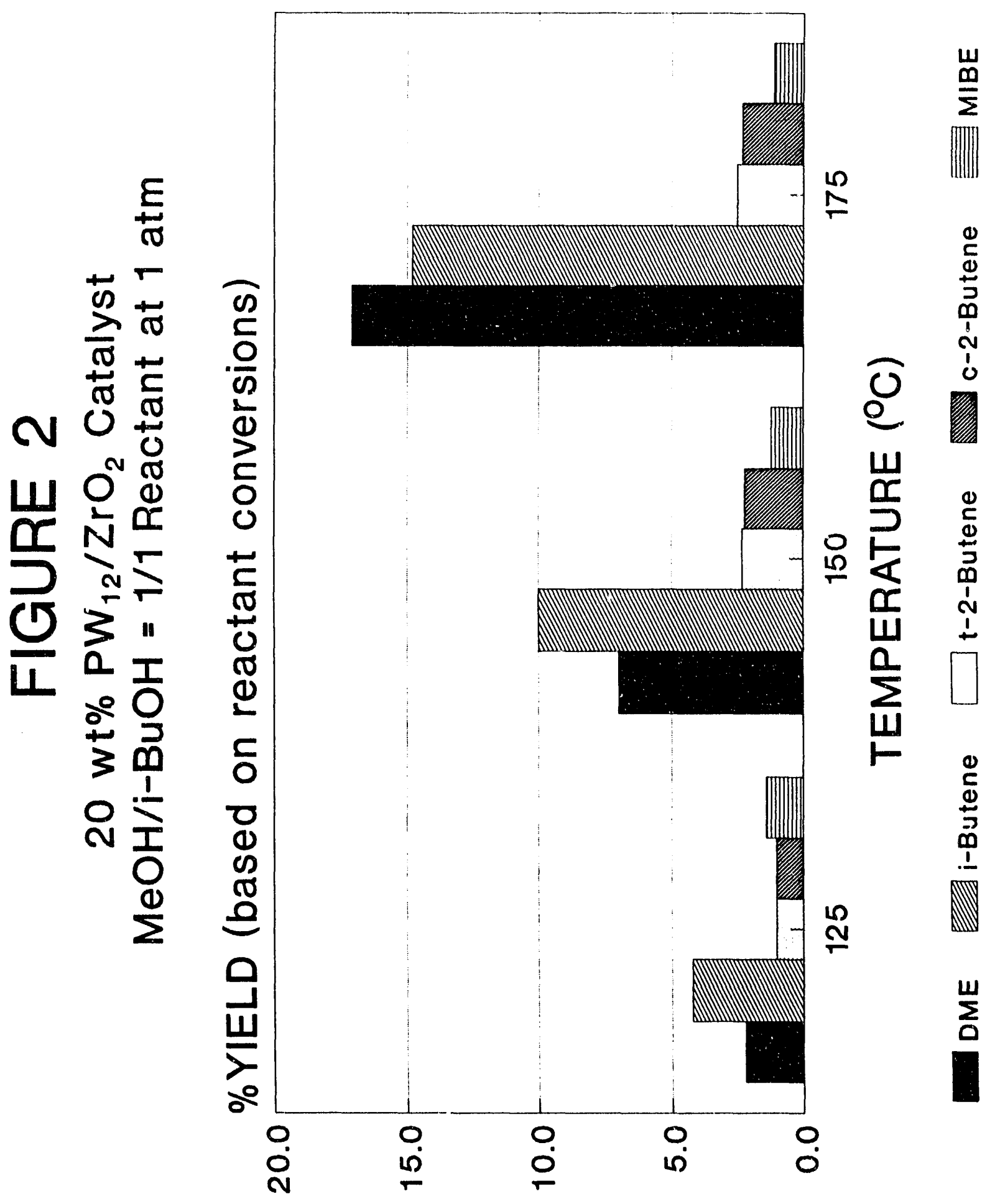




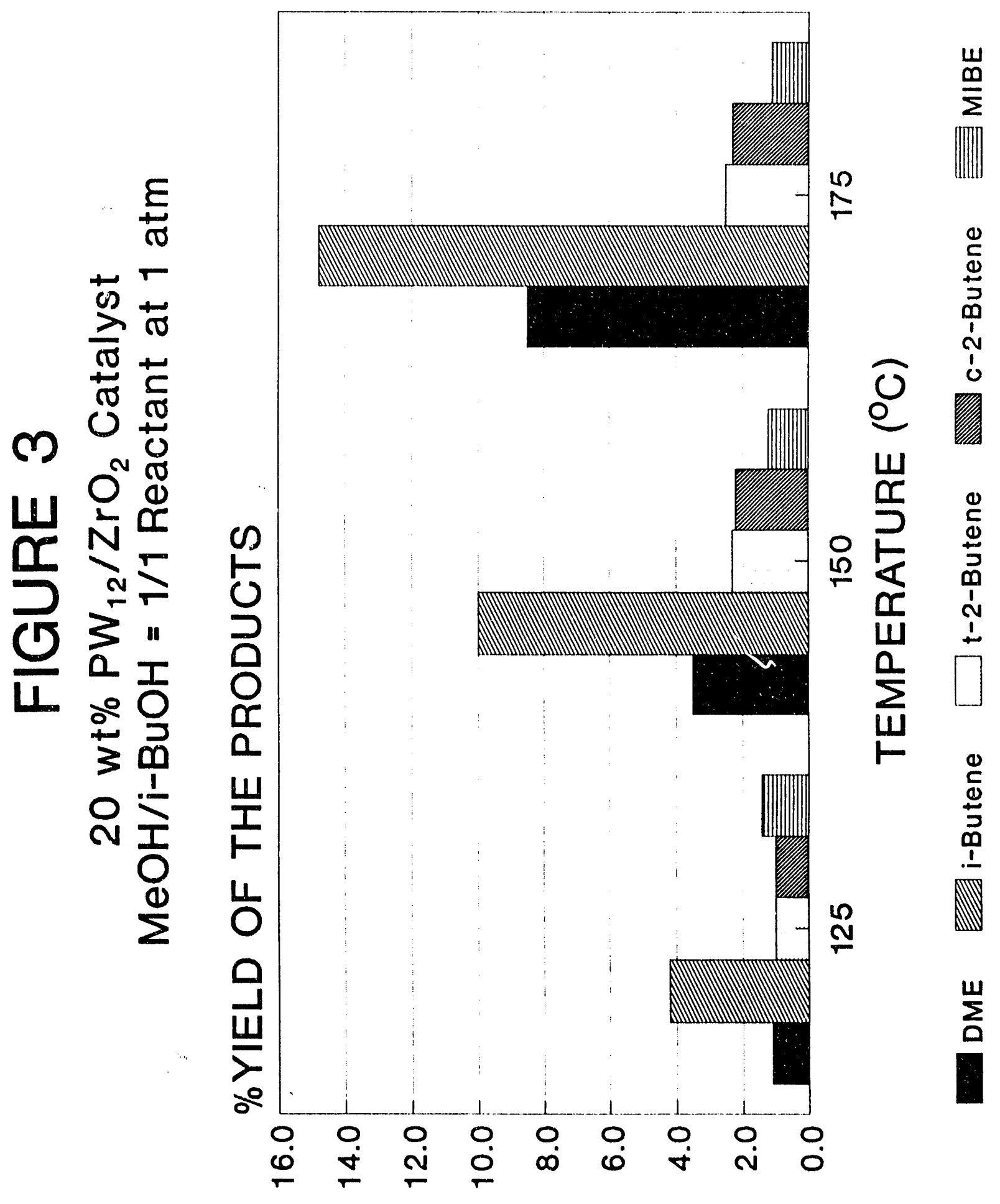


product formed with a space time yield of $0.254 \mathrm{~mol}^{*} \mathrm{~kg}^{-1 *} \mathrm{hr}^{-1}$, while the rate of production of DME was $0.147 \mathrm{~mol}^{*} \mathrm{~kg}^{-1 *} \mathrm{hr}^{-1}$. This means that more methanol was converted to DME than the quantity of isobutanol that was converted to isobutene. However, based on the quanitites of products formed, the molar selectivities were 29.2\% DME, 50.5\% isobutene, 8.5\% trans-2-butene, $8.0 \%$ cis-2-butene, and 3.8\% MIBE.

The overall conversions at $175^{\circ} \mathrm{C}$ corresponded to $20.7 \mathrm{~mol} \%$ conversion of isobutanol to products and $18.2 \mathrm{~mol} \%$ of methanol to products. The \%yields are shown in Figure 2, and these are based on the conversion levels of the reactants. Just for comparison purposes, the \%yields are shown in Figure 3 on the basis of product molar composition, where the only difference between Figures 2 and 3 are in the values of DME since DME contains two methyl groups, as already discussed. Earlier, it had been found that pure $\mathrm{ZrO}_{2}$ was totally inactive fo. these reactions. Therefore, the activity of the $\mathrm{PW}_{12} / \mathrm{ZrO}_{2}$ catalyst can be attributed to the presence of the phosphotungstic acid $\left(\mathrm{H}_{3} \mathrm{PW}_{12} \mathrm{O}_{40}\right)$.

The niobic acid catalyst was essentially inactive at and below $175^{\circ} \mathrm{C}$, as shown in Figures 4 and 5. At $200^{\circ} \mathrm{C}$, the methanol and isobutanol conversions levels were 9.3 and $10.5 \%$, respectively. When higher temperatures were used, most notably at $225^{\circ} \mathrm{C}$, the activity and selectivity approached that seen for the best catalyst tested so far, the $\mathrm{ZrO}_{2} / \mathrm{SO}_{4}{ }^{2-}$ catalyst. At $225^{\circ} \mathrm{C}$, as shown in Figure 4 , this $\mathrm{Nb}_{2} \mathrm{O}_{5} \cdot \mathrm{H}_{2} \mathrm{O}$ niobic acid catalyst produced $1.0 \mathrm{~mol}^{*} \mathrm{~kg}^{-1 *} \mathrm{hr}^{-1}$ of isobutene and only $0.13 \mathrm{~mol}^{*} \mathrm{~kg}^{-1 *} \mathrm{hr}^{-1}$ of DME. In comparison, the $\mathrm{ZrO}_{2} / \mathrm{SO}_{4}{ }_{4}^{2-}$ catalyst produced $1.1 \mathrm{~mol}^{*} \mathrm{~kg}^{-1 *} \mathrm{hr}^{-1}$ of isobutene and only 0.10 $\mathrm{mol}^{*} \mathrm{~kg}^{-1 *} \mathrm{hr}^{-1}$ of DME, which was achieved at the lower temperature of $175^{\circ} \mathrm{C} \mathrm{(3).} \mathrm{With}$ the $\mathrm{Nb}_{2} \mathrm{O}_{5}$ cataiyst at $225^{\circ} \mathrm{C}$, the reactant conversions were $70.2 \%$ isobutanol and $19.6 \%$ methanol to products, and Figure 5 shows that the \%yields of isobutanol to isobutene and of methanoi to D̀ंíE were 58.7 anủ $15.5 \%$, respectiveiy. 


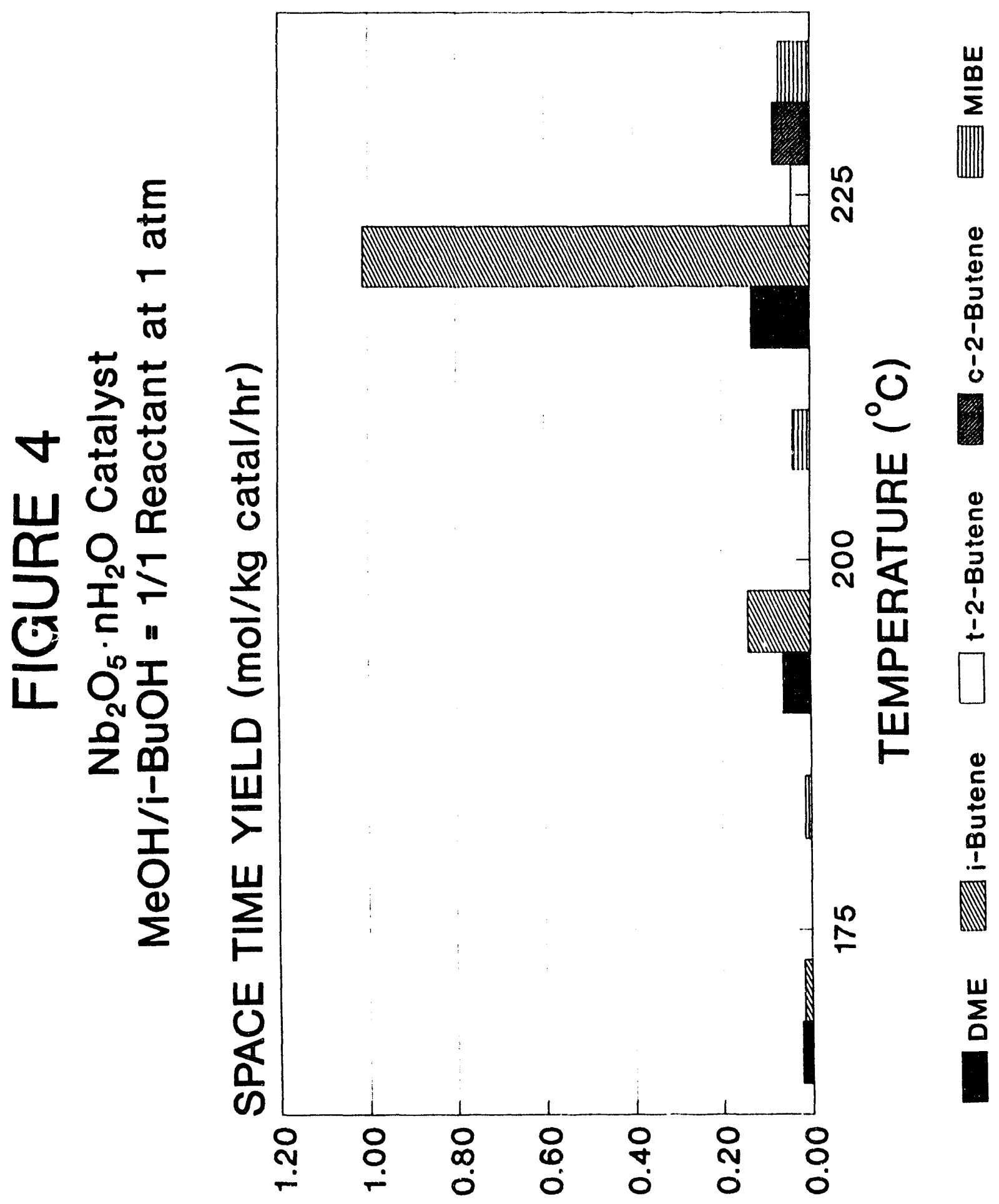




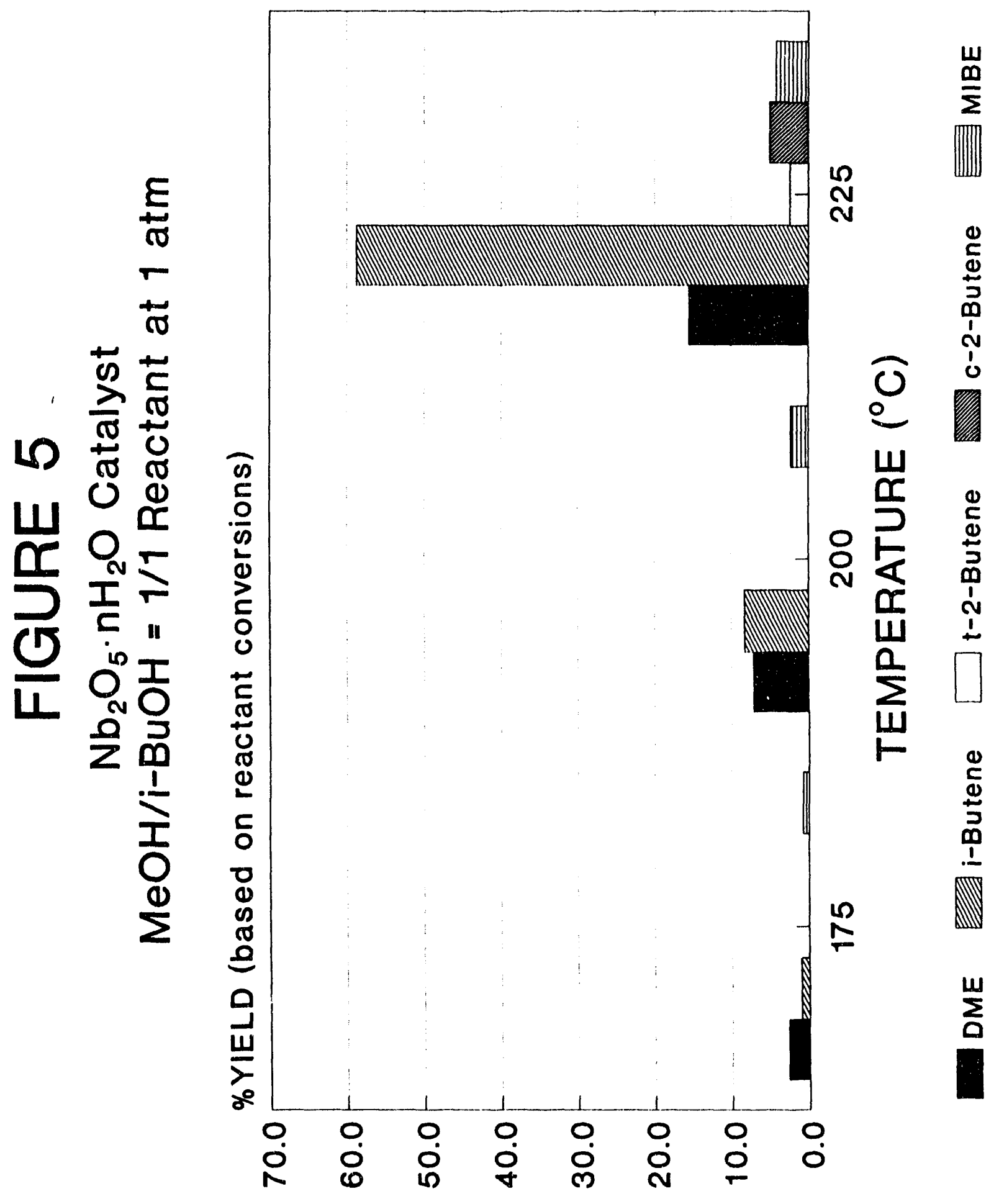


The catalytic results for the $\mathrm{Fe} / \mathrm{Mn} / \mathrm{ZrO}_{2} / \mathrm{SO}_{4}{ }^{2-}$ catalyst were similar at the higher reaction temperatures employed to those of the $\mathrm{ZrO}_{2} / \mathrm{SO}_{4}{ }^{2-}$ catalyst (3). At $175^{\circ} \mathrm{C}$, the $\mathrm{Fe}$ and Mn-doped catalyst produced $0.91 \mathrm{~mol}^{*} \mathrm{~kg}^{-1 *} \mathrm{hr}^{-1}$ of isobutene and $0.03 \mathrm{~mol}^{*} \mathrm{~kg}^{-1 *} \mathrm{hr}^{-1}$ of DME, as shown in Figure 6. However, at lower temperature, the $\mathrm{Fe} / \mathrm{Mn} / \mathrm{ZrO}_{2} / \mathrm{SO}_{4}{ }^{2-}$ catalyst as prepared here was considerably less active than the $\mathrm{ZrO}_{2} / \mathrm{SO}_{4}{ }^{2-}$ catalyst. For example, at $150^{\circ} \mathrm{C}$ the yield of isobutene was only $0.24 \mathrm{~mol}^{*} \mathrm{~kg}^{-1 *} \mathrm{hr}^{-1}$ for $\mathrm{Fe} / \mathrm{Mn} / \mathrm{ZrO}_{2} / \mathrm{SO}_{4}{ }^{2-}$ compared to $0.61 \mathrm{~mol}^{*} \mathrm{~kg}^{-1 *} \mathrm{hr}^{-1}$ for $\mathrm{ZrO}_{2} / \mathrm{SO}_{4}{ }^{2-}$ (3).

This $\mathrm{Fe} / \mathrm{Mn} / \mathrm{ZrO}_{2} / \mathrm{SO}_{4}{ }^{2-}$ catalyst exhibited a greater selectivity in activating isobutanol relative to methanol than the $\mathrm{PW}_{12} / \mathrm{ZrO}_{2}$ catalyst and the $\mathrm{Nb}_{2} \mathrm{O}_{5} \cdot \mathrm{H}_{2} \mathrm{O}$ catalyst. The overall conversion levels for the former sulfated catalyst at $175^{\circ} \mathrm{C}$ were $61.3 \%$ isobutanol to products and $6.2 \%$ methanol to products. The \%yields for this catalyst are shown in Figure 7. Figures 6 and 7 demonstrate that this catalyst was quite selective for the dehydration of isobutanol to isobutene, specifically $86.6 \mathrm{~mol} \%$ of the $\mathrm{C}_{4}$-containing products was isobutene and $84.4 \mathrm{~mol} \%$ of all significant products, not including water, was isobutene.

\section{B. The Effect of Water on Reaction of $\mathrm{MeOH} / \mathrm{i}-\mathrm{BuOH}$ Over $\mathrm{ZrO}_{2} / \mathrm{SO}_{4}{ }^{2-}$}

A major product of any conversion of the methanol/isobutanol mixture over solid acid catalysts is water. The presence of water can influence the type of acid sites present, e.g. it can often convert Lewis acid sites into Brønsted acid sites. In addition, water may also lead to a retarding effect on the reaction, as was reported for alumina earlier (4). This latter effect may arise by competitive adsorption of water and partial blockage of active sites. In this experiment, reaction conditions were chosen where a $2 / 1$ mixture of $\mathrm{MeOH} / \mathrm{i}$ $\mathrm{BuOH}$ was reacted over a $1 \% \mathrm{SO}_{4}{ }^{2-} / \mathrm{ZrO}_{2}$ catalyst at $157^{\circ} \mathrm{C}$ and 1 atm within the differential regime as described in the previous quarterly report (5). Specifically, the 


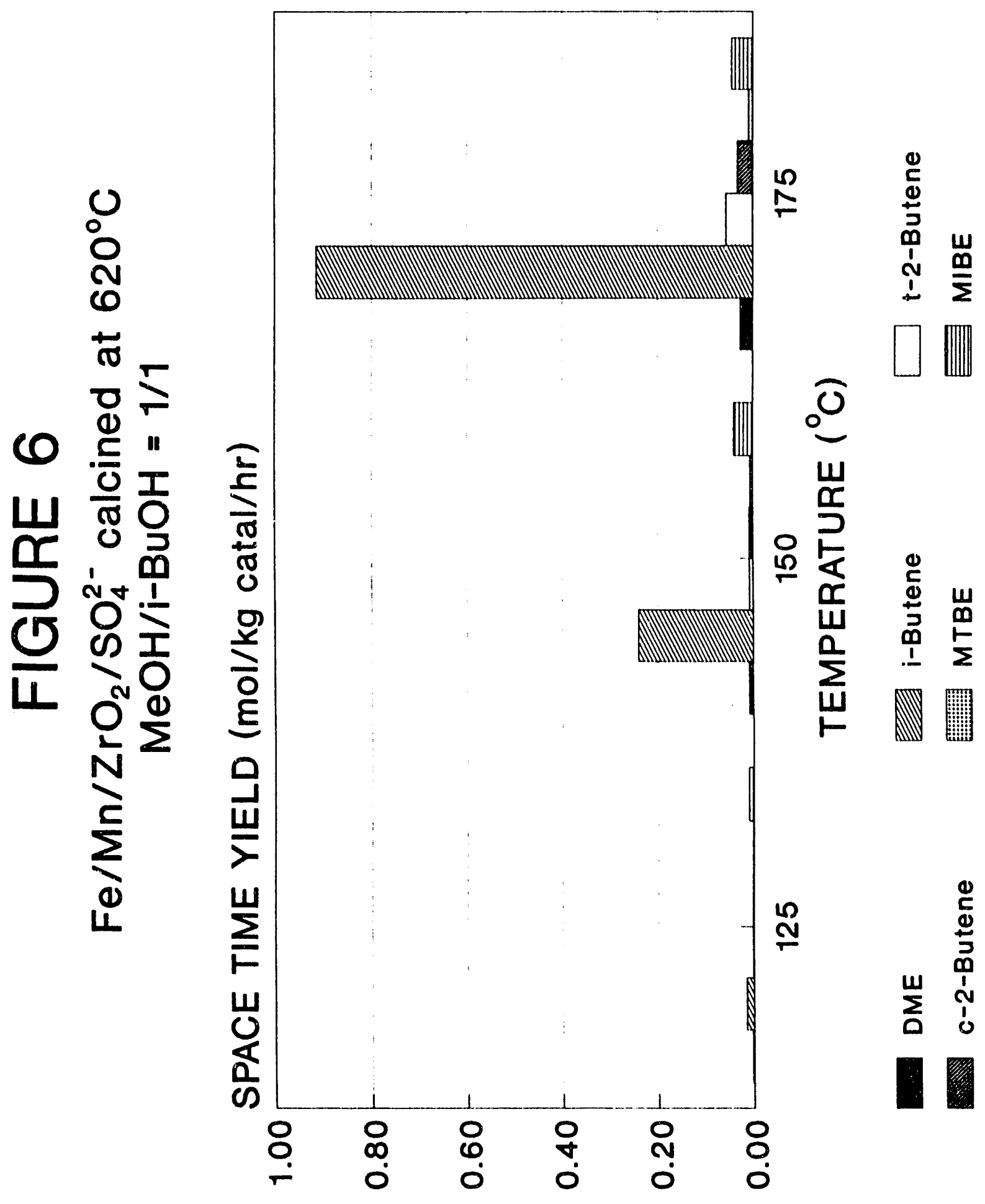




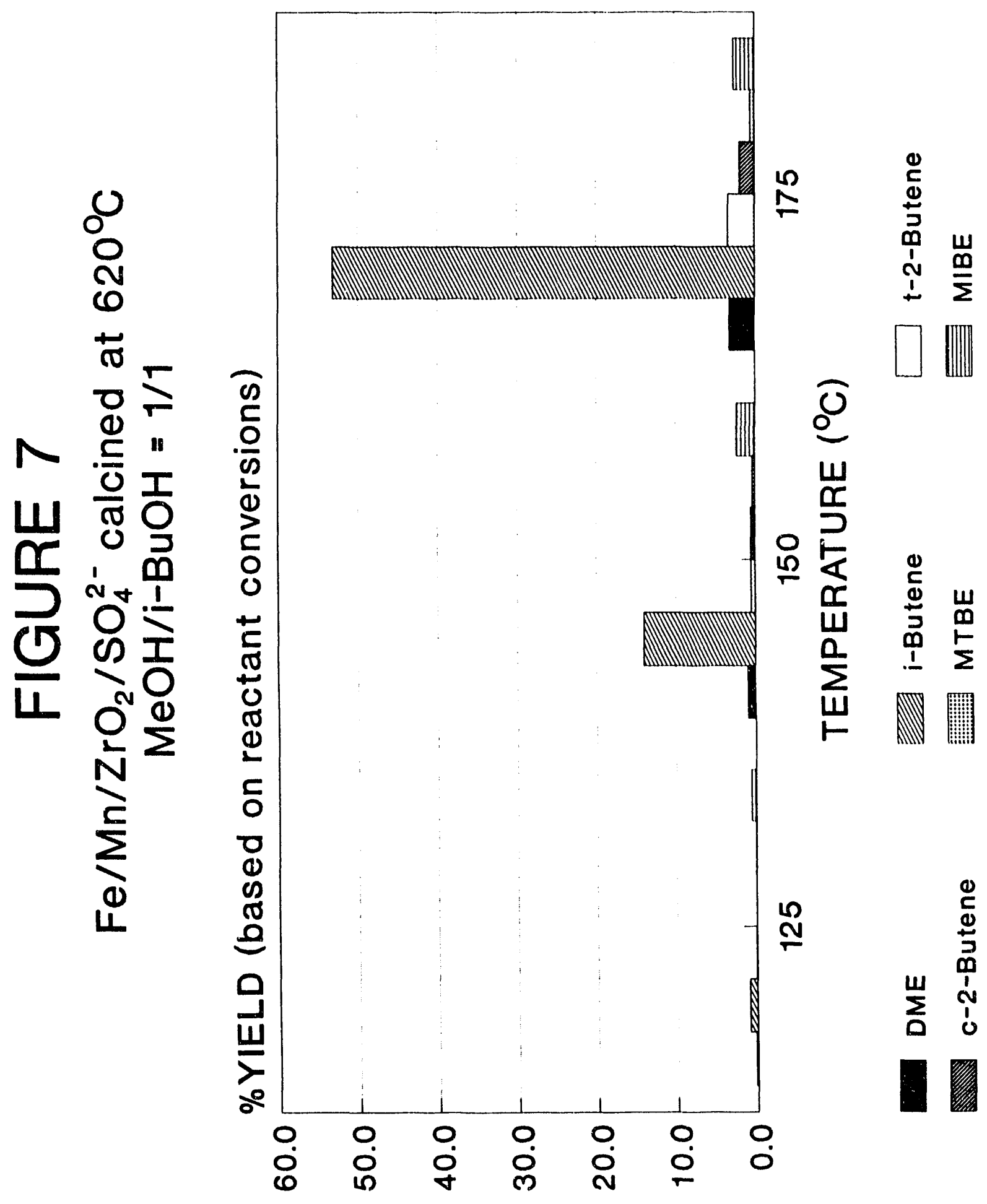


conditions were:

$\begin{array}{ll}\text { Temperature } & 157^{\circ} \mathrm{C} \\ \text { Pressure } & 1 \mathrm{~atm} \\ \text { Water feed } & 0,1.08,2.16 \mathrm{~mol} / \mathrm{kg} \mathrm{catalyst} / \mathrm{hr} \\ \text { Methanol feed } & 43.3 \mathrm{~mol} / \mathrm{kg} \mathrm{catalyst} / \mathrm{hr} \\ \text { Isobutanol feed } & 21.6 \mathrm{~mol} / \mathrm{kg} \text { catalyst } / \mathrm{hr} \\ \text { He }+\mathrm{N}_{2} \text { flow } & 762 \mathrm{~mol} / \mathrm{kg} \text { catalyst } / \mathrm{hr} \\ \text { Catalyst weight } & 0.4 \mathrm{~g}\end{array}$

The catalyst was first exposed to the dry $2 / 1 \mathrm{MeOH} / \mathrm{i}-\mathrm{BuOH}$ mixture, then to a $\mathrm{MeOH} / \mathrm{i}-\mathrm{BuOH} / \mathrm{H}_{2} \mathrm{O}=2 / 1 / 0.05$ mixture, followed by a $2 / 1 / 0.1$ mixture. The feed was again switched to the dry $2 / 1$ mixture and then back to the $2 / 1 / 0.1 \mathrm{MeOH} / \mathrm{i}-\mathrm{BuOH} / \mathrm{H}_{2} \mathrm{O}$ mixture. The results of this experiment are shown in Figure 8. The high gas gas hourly space velocity (GHSV) of the carrier gas ensured low conversion levels of the reactants, e.g. at $100 \mathrm{hr}$ on stream the conversion of isobutanol to products was about $4 \mathrm{~mol} \%$ ( $\approx 3.7$ \%yield of isobutene). It can be seen from Figure 8 that the catalyst gradually and steadily deactivated with time on stream. However, the presence or absence of water in the feed did not affect the yield or selectivity of the products, which consisted mainly of isobutene.

Another experiment with a fresh catalyst was carried out wherein it was first exposed to the water-containing reactant mixture and then to the dry alcohol reactant mixture. No difference in effect from the previous experiment was observed. These results differ from those observed earlier for alumina, where a strong inhibition, ca. 30\%, in the production of DME, MIBE, and isobutene was noted (4). Those results were explained with the knowledge that alumina is known to possess strong acidity only in the form of Lewis acid sites that depend in number and strength on the degree of hydration of the surface. In the case of $\mathrm{ZrO}_{2} / \mathrm{SO}_{4}{ }^{2-}$, however, Arata has shown (6) that Lewis acid sites can be converted to strong Brønsted acid sites upon exposure to low partial pressures of water, i.e. 5 torr. In 


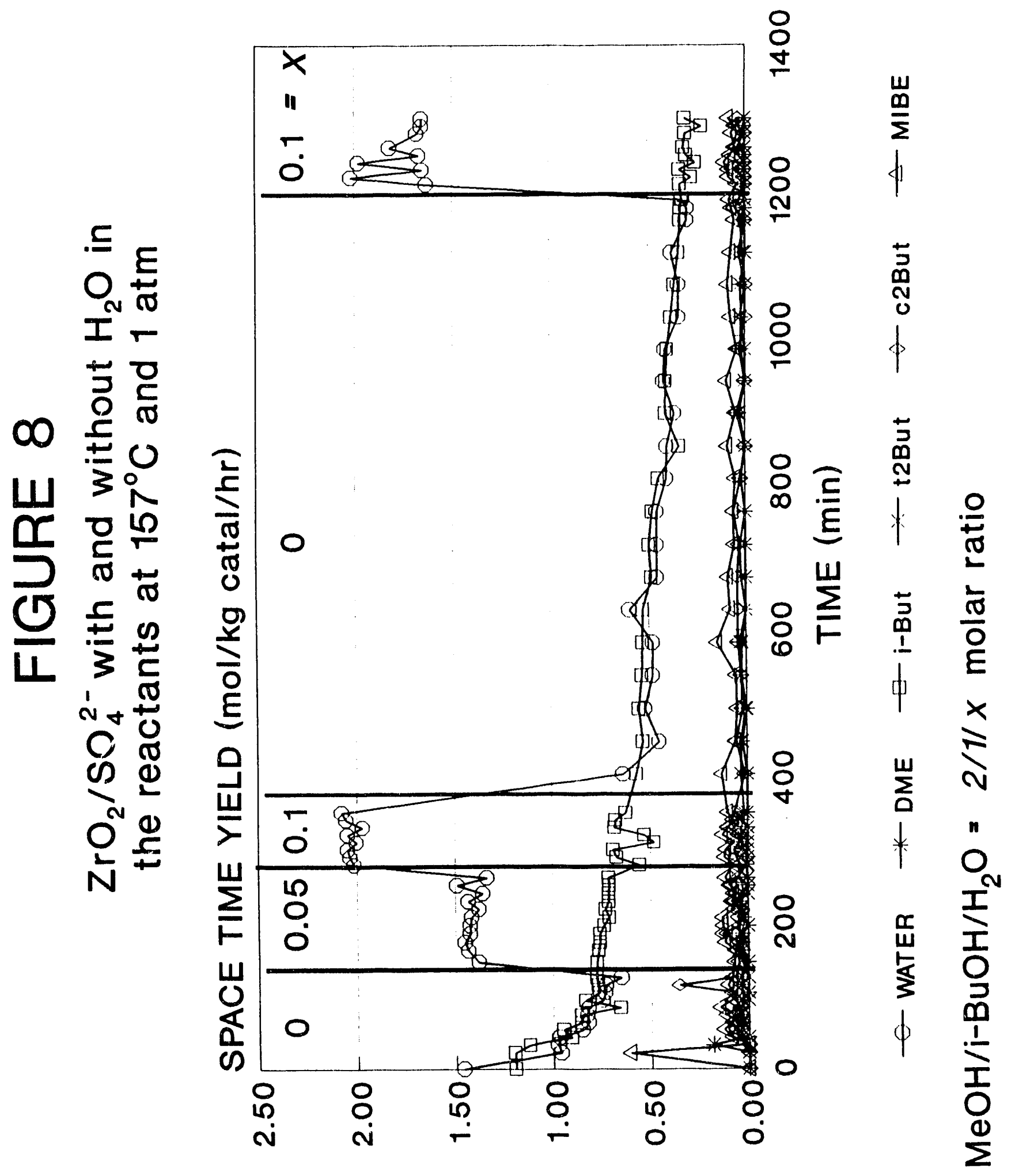


the present investigation, in the "dry" runs where the only water present was that formed as a product of the reaction, the partial pressure of water was less than 1 torr. In the "wet" runs, the partial pressure of water was about 3 torr. Under high conversion conditions, the water produced during reaction can reach rather high levels. For example, over the $\mathrm{Fe} / \mathrm{Mn} / \mathrm{ZrO}_{2} / \mathrm{SO}_{4}{ }^{2-}$ catalyst at $175^{\circ} \mathrm{C}$ (Figure 6), the water partial pressure generated by isobutanol dehydration corresponded to $\approx 42$ torr, under non-differential reaction conditions. This approached the initial partial pressures of isobutanol and methanol reactants, which was $\approx 67$ torr. Thus, perhaps additional experiments need to be carried out under differential reaction conditions, but where appreciably higher water injection rates are utilized to maintain higher levels of water partial pressures over the catalyst. We are currently investigating whether the state of this catalyst changes drastically in the presence of water during the course of different reaction conditions through direct spectroscopic means.

\section{Surface Area Measurements}

Surface areas have been determined for samples of $\mathrm{Fe} / \mathrm{Mn} / \mathrm{ZrO}_{2} / \mathrm{SO}_{4}^{2-}$ and niobic acid $\left(\mathrm{Nb}_{2} \mathrm{O}_{5} \cdot \mathrm{xH}_{2} \mathrm{O}\right)$, prepared as described in Section $\mathrm{A}$ of this report, as well as the 12phosphotungstic acid on silica catalyst $\left(\mathrm{PW}_{12} / \mathrm{SiO}_{2}\right)$ that was prepared and tested as described in the previous quarterly report (5).

\section{Experimental}

Samples were analyzed with a Gemini 2360 Analyzer instrument from Micromeritics. Surface area was determined at $-196^{\circ} \mathrm{C}$ by using the BET multipoint technique. Points were chosen so that $\mathrm{p} / \mathrm{p}_{0}$ varied from 0.05 to 0.3 . This yielded a linear BET-plot and accurate determination of the surface area. Samples were generally degassed at $300^{\circ} \mathrm{C}$ for $2 \mathrm{hr}$ prior 
to exposure of $\mathrm{N}_{2}$ at $-196^{\circ} \mathrm{C}$.

\section{Results}

Surface areas were determined for $\mathrm{Fe} / \mathrm{Mn} / \mathrm{ZrO}_{2} / \mathrm{SO}_{4}^{2-}$ samples dried at $100^{\circ} \mathrm{C}$ and after calcination at $620^{\circ} \mathrm{C}$. The uncalcined sample of $\mathrm{Fe} / \mathrm{Mn} / \mathrm{ZrO}_{2} / \mathrm{SO}_{4}^{2-}$ was degassed at $120^{\circ} \mathrm{C}$, whereas the calcined $\mathrm{Fe} / \mathrm{Mn} / \mathrm{ZrO}_{2} / \mathrm{SO}_{4}^{2-}$, niobic acid, and phosphotungstic acid on silica $\left(\mathrm{PW}_{12} / \mathrm{SiO}_{2}\right)$ catalysts were degassed at $300^{\circ} \mathrm{C}$. The measured surface areas are given in Table 1. The surface area determined for calcined $\mathrm{Fe} / \mathrm{Mn} / \mathrm{ZrO}_{2} / \mathrm{SO}_{4}{ }^{2-}$ is in good agreement with the reported value of $97 \mathrm{~m}^{2} / \mathrm{g}(2)$.

Table 1. Surface Areas

\begin{tabular}{|l|c|}
\hline \multicolumn{1}{|c|}{ Catalyst } & Surface Area $\left(\mathrm{m}^{2} / \mathrm{g}\right)$ \\
\hline $\mathrm{Fe} / \mathrm{Mn} / \mathrm{ZrO}_{2} / \mathrm{SO}_{4}^{2-}$ dried to $100^{\circ} \mathrm{C}$ & 219 \\
\hline $\mathrm{Fe} / \mathrm{Mn} / \mathrm{ZrO}_{2} / \mathrm{SO}_{4}^{2-}$ calcined to $620^{\circ} \mathrm{C}$ & 83 \\
\hline Niobic Acid & 118 \\
\hline$\left(\mathrm{PW}_{12} / \mathrm{SiO}_{2}\right)$ & 218 \\
\hline
\end{tabular}

\section{D. ${ }^{1} \mathrm{H}$ NMR to Resolve Whether 1-Butene is a Product}

Our main technique to identify reactants and products is gas chromatography (GC). Isobutene is an abundant product when isobutanol is dehydrated over acid catalysts. As shown, other possible dehydration products are cis-2-butene, trans-2-butene and 1-butene. By using GC, with our present method of separation using a Cp-Sil-5 capillary WCOT column, isobutene can be separated from cis-2-butene and trans-2-butene but not from 1butene. To resolve if and how much 1-butene is present as a product over the sulfated zirconia, ${ }^{1} \mathrm{H}$ NMR was utilized to further distinguish the $\mathrm{C}_{4}$ products. 


\section{Experimental}

Products from dehydration of isobutanol over sulfated zirconia were collected in a $\mathrm{N}_{2}(l)$ cooled trap. The product stream was dried with molecular sieves prior to the trap to remove as much water as possible. As standards, individual samples of pure 1-butene, isobutene, cis-2-butene, and trans-2-butene were collected from their respective gas cylinders.

A $500 \mathrm{MHz}$ Bruker AM500 NMR instrument was utilized for these analyses. The spectra were acquired from 0 to $8 \mathrm{ppm}$ at approximately $-20^{\circ} \mathrm{C}$. All samples were diluted approximately 1:4 with $\mathrm{CDCl}_{3}$. The pure butene samples were used to calibrate peak positions.

\section{$\underline{\text { Results }}$}

Isobutene has distinctive ${ }^{1} \mathrm{H}$ NMR peaks at 4.65 and $1.7 \mathrm{ppm}$ (Figure 9), whereas 1butene has groups of peaks at approximately 5.9, 4.9, 2.1, and $1.0 \mathrm{ppm}$ (Figure 10). The spectra of the pure butenes were compared to the spectrum of the dehydration products of isobutanol (Figure 11).

From the NMR spectra, it is concluded that 1-butene was indeed present in the product stream in a small amount. By integrating the NMR peaks at 5.9 and $4.65 \mathrm{ppm}$, the quantity of 1-butene could be determined. Neither cis-2-butene nor trans-2-butene have any peaks in this region. It was found that the product stream consist of $\leq 3 \% 1$-butene. 

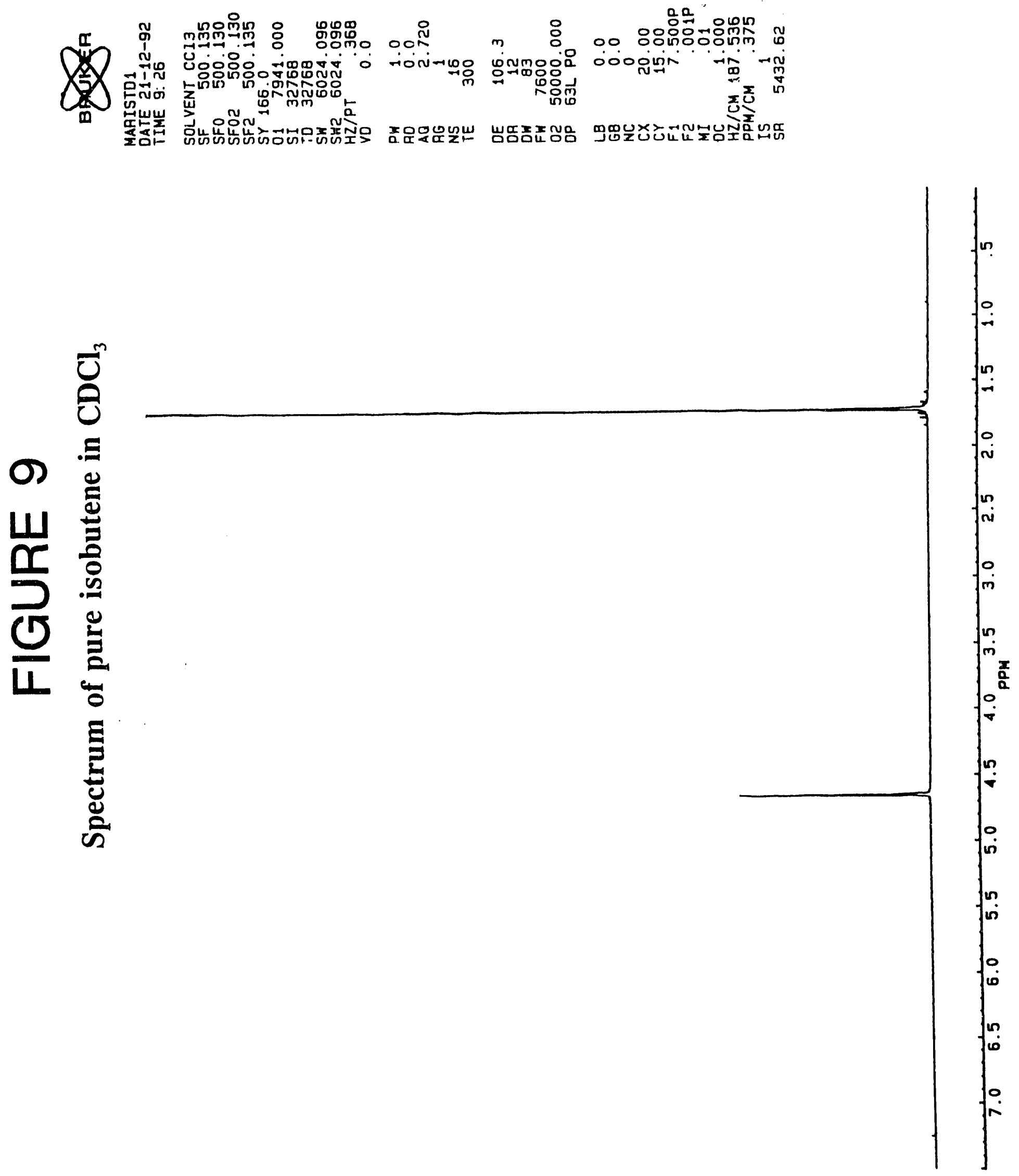


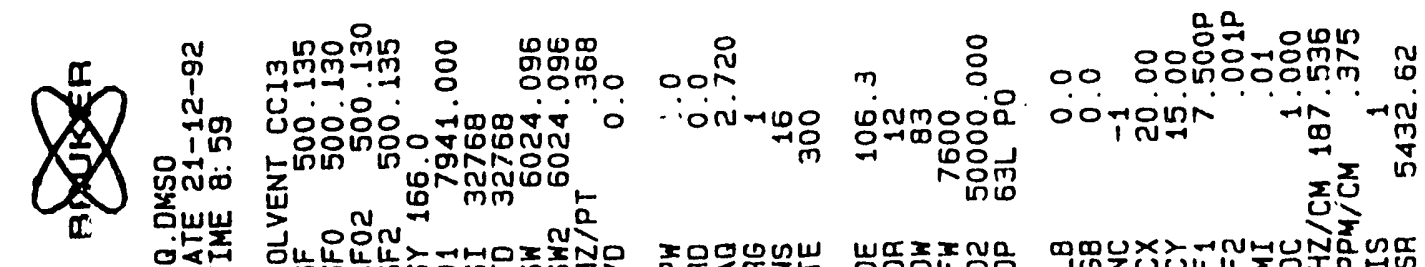

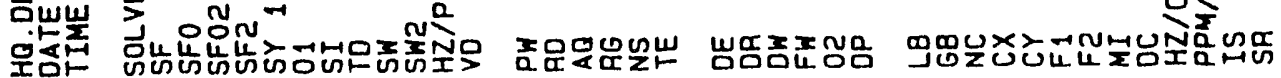

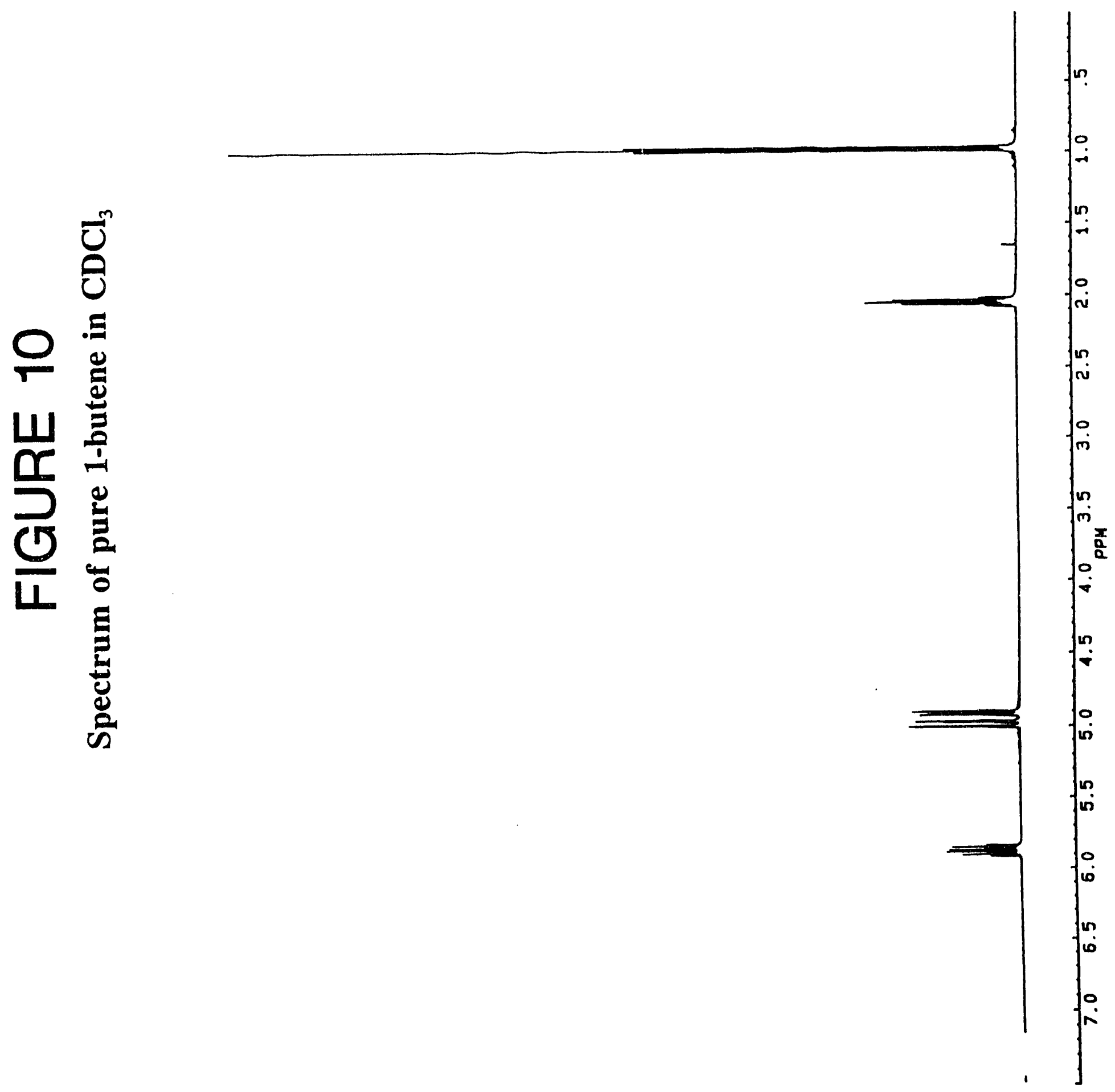



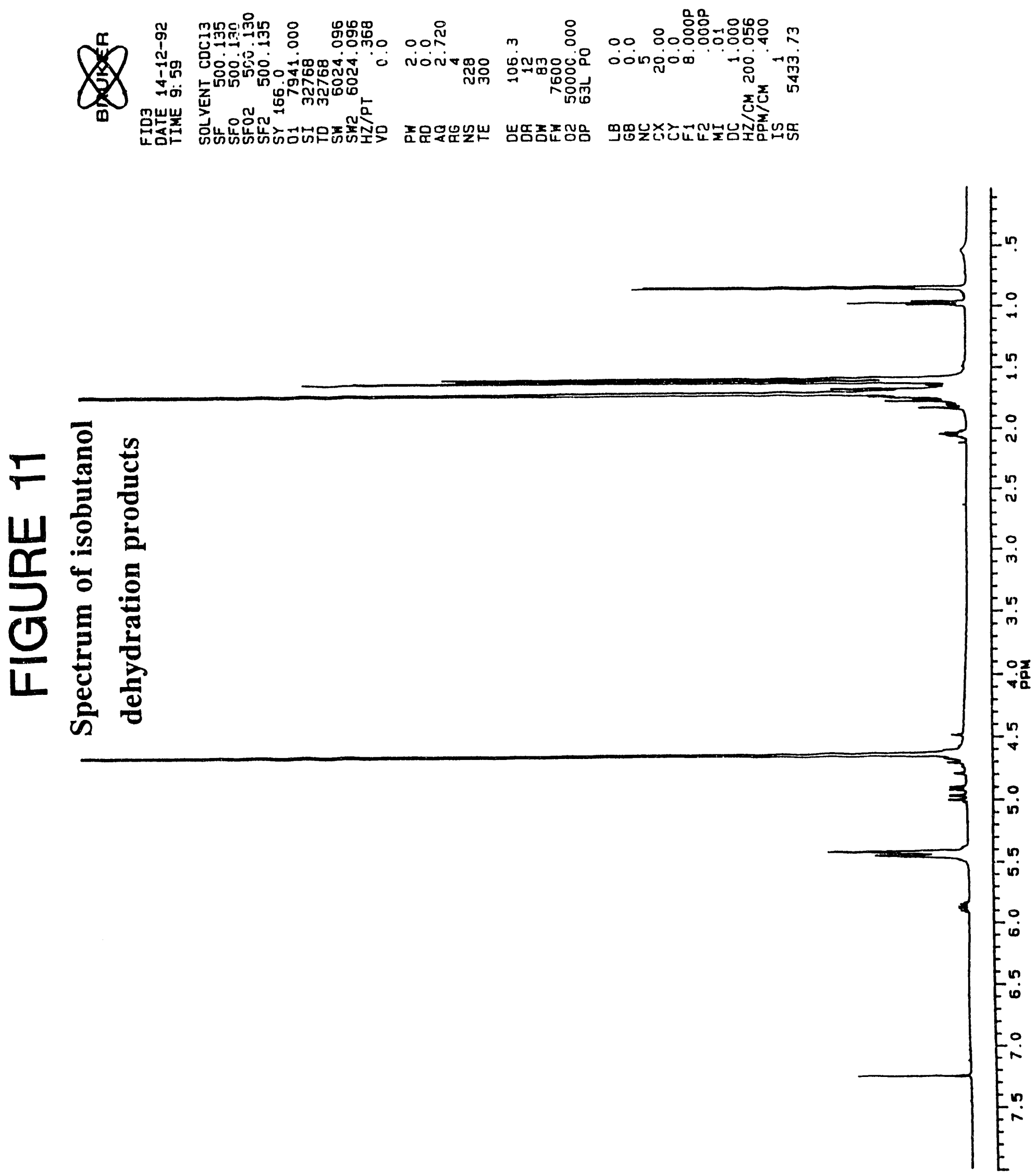


\section{References}

1. Tanabe, K., Misono, M., Ono, Y., and Hattori, H., "New Solid Acids and Bases," Elsevier, Amsterdam (1989) p 61.

2. Hsu, C.-Y., Heimbuch, C. R., Armes, C. T., and Gates, B. C., J. Chem. Soc., Chem. Commun, (1992) 3645.

3. Klier, K., Herman, R. G., Johansson, M., and Feeley, O. C., Quarterly Technical Progress Report DOE/PC/90044-5 (January 1992).

4. Klier, K., Herman, R. G.. Johansson, M. A., and Feeley, O. C., Quarterly Technical Progress Report DOE/PC/90044-6 (A.pril 1992).

5. Klier, K., Herman, R. G., Feeley, O. C., and Johansson, M. A., Quarterly Technical Progress Report DOE/PC/90044-8 (October 1992).

6. Arata, K., Adv. Catal., 37 (1990) 165. 

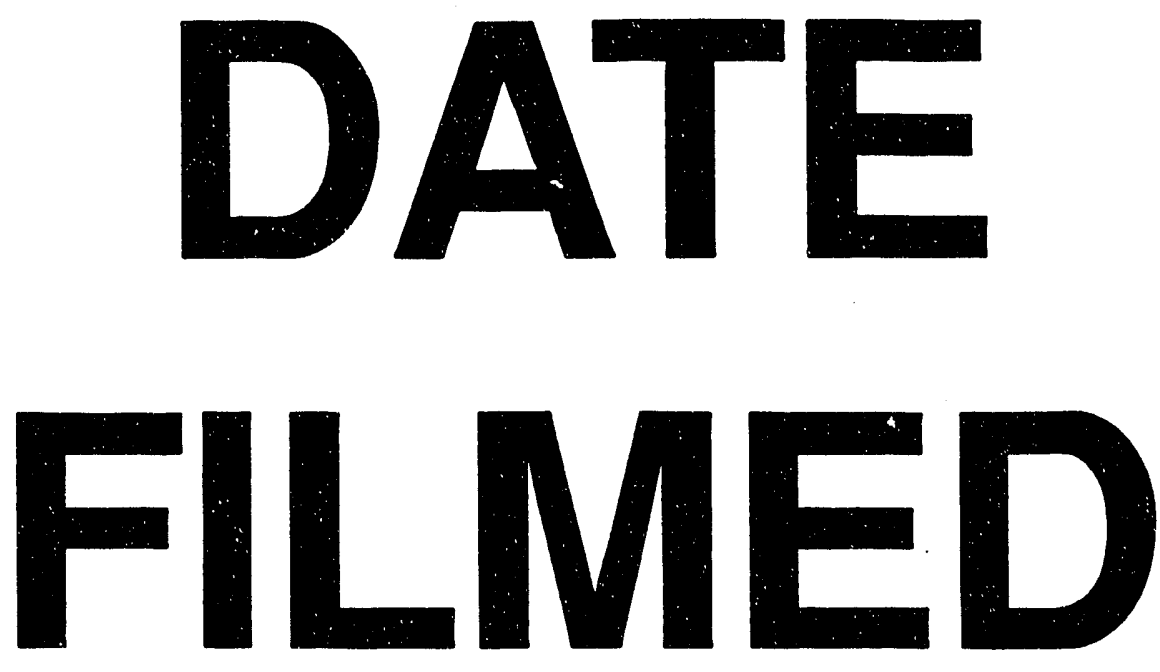

$8 / 19 / 93$
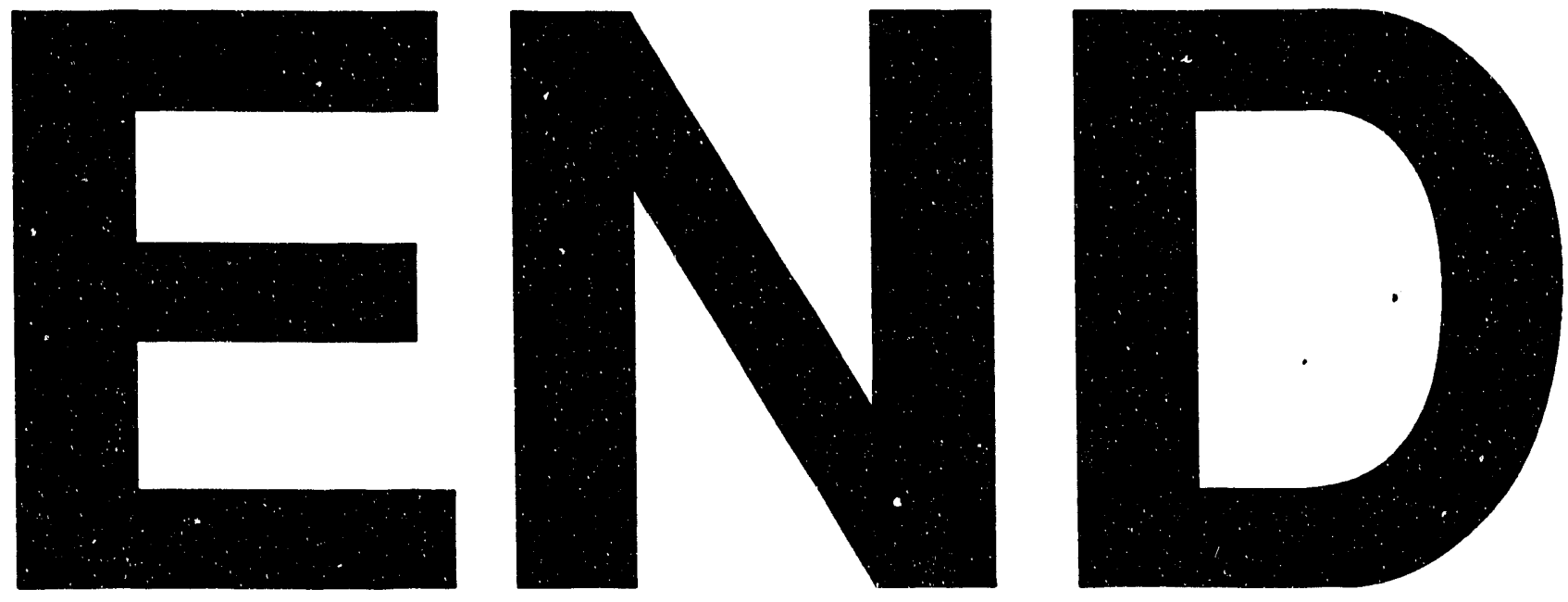
